\title{
OPEN Activation of antioxidative and detoxificative systems in Brassica juncea L. plants against the toxicity of heavy metals
}

\author{
Arleta Małecka ${ }^{1 凶}$, Agnieszka Konkolewska², Anetta Hanć3 ${ }^{3}$, Liliana Ciszewska ${ }^{2}$, \\ Aleksandra Maria Staszak ${ }^{4}$, Wieslawa Jarmuszkiewicz ${ }^{5}$ \& Ewelina Ratajczak ${ }^{6}$
}

Plant metal hyperaccumulators, to which Brassica juncea belongs, must have very efficient defence mechanisms that enable growth and development in an environment polluted with various heavy metals. $B$. juncea (Indiana mustard) v. Małopolska was exposed to the activity of trace elements such as cadmium (Cd), copper (Cu), lead (Pb), and zinc ( $\mathrm{Zn}$ ) in combinations: CuPb, CuCd, CuZn, PbCd, $\mathrm{PbZn}$, and $\mathrm{ZnCd}$ in a concentration of $25 \mu \mathrm{M}$ each for $96 \mathrm{~h}$ during control cultivation. We observed a clear tendency for metal uptake and accumulation in above-ground parts which is characteristic of hyperaccumulators. The combinations of CuCd, CuZn, and PbCd inhibited the development of the seedlings the most. The used metal combinations increased the levels of reactive oxygen species (ROS) such as: hydrogen peroxide $\left(\mathrm{H}_{2} \mathrm{O}_{2}\right)$, superoxide anion $\left(\mathrm{O}_{2} \cdot{ }^{-}\right)$and oxidized proteins in $B$. juncea organs, generating oxidative stress conditions in the cells. We determined the level of transcription of the respective defence proteins of the detoxification and antioxidant systems. We have shown that in the first $24 \mathrm{~h}$ of stress condiction, activation of glutamylcysteine- $\gamma$ synthetase (yECS) and glutathione reductase (GR1) enzymes related to the detoxification of heavy metals is important for $B$. juncea plants. In addition, the data provide important information on how plants respond to the presence of heavy metals in the first days of stress conditions.

Anthropogenic activity increases year by year, including rapid industrialisation, urbanisation, the development of mining, metallurgy, fuel combustion, the use of artificial fertilizers, sewage sludge, and plastics, all of which accelerates the release of various toxic trace metals into the environment. Heavy metals affect the development and growth of the whole plant because they influence many basic physiological processes, including photosynthesis and respiration ${ }^{1,2}$. The constant accumulation of heavy metals in the soil can pose a serious threat to living organisms, both plants and animals ${ }^{3,4}$. Because biological organisms are unable to degrade metals, they remain in parts of the body and in the environment ${ }^{5,6}$. Heavy metals are categorized as essential and non-essential. Essential metals, including copper $(\mathrm{Cu})$ and zinc $(\mathrm{Zn})$, have important regulatory roles in a number of biological processes, while non-essential metals, such as cadmium $(\mathrm{Cd})$ and lead $(\mathrm{Pb})$, possess unknown biological functions, which are potentially highly toxic to plants ${ }^{5,7,8}$. The toxicity level of non-essential metals depends on their concentration and their bioavailability. Bioavailability of metals depends on abiotic variables, including physical factors, for example, soil structure. It also depends on biotic elements, for example, microbial and plant species ${ }^{9,10}$. Heavy metals necessary in high concentrations may also be harmful to organisms ${ }^{1}$. To date, more than 400 plant species from different families, such as Asteraceae, Brassicaceae, Violaceae, Poaceae, and Fabaceae, have been identified as capable of tolerating high levels of heavy metals in the soil. Among plants of the Brassicaceae family there are almost 80 plant species with the potential for heavy metal accumulation. Many authors have confirmed that

${ }^{1}$ Department of Biotechnology, Institute of Molecular and Biotechnology, Adam Mickiewicz University, Collegium Biologicum, Uniwersytetu Poznańskiego 6, 61-614 Poznań, Poland. ²Department of Biochemistry, Institute of Molecular Biology and Biotechnology, Adam Mickiewicz University, Collegium Biologicum, Uniwersytetu Poznańskiego 6, 61-614 Poznań, Poland. ${ }^{3}$ Department of Trace Analysis, Faculty of Chemistry, Adam Mickiewicz University, Uniwersytetu Poznańskiego 8, 61-614 Poznań, Poland. "Plant Physiology Department, Faculty of Biology, University of Bialystok, Ciółkowskiego 1J, 15-245 Bialystok, Poland. ${ }^{5}$ Laboratory of Mitochondrium Biochemistry, Department of Bioenergetics, Institute of Molecular and Biotechnology, Adam Mickiewicz University, Collegium Biologicum, Uniwersytetu Poznańskiego 6, 61-614 Poznań, Poland. ${ }^{6}$ Institute of Dendrology, Polish Academy of Sciences, Parkowa 35, 62-035 Kórnik, Poland. ${ }^{\square}$ email: arletam@amu.edu.pl 
Brassica juncea is able to accumulate significant amounts of some trace elements, such as $\mathrm{Pb}^{11}, \mathrm{~Pb}, \mathrm{Cd}^{11,12}, \mathrm{Se}^{13}$, $\mathrm{Zn}, \mathrm{Cr}, \mathrm{Cu}$, and $\mathrm{Au}^{14}, \mathrm{Cr}, \mathrm{Cu}, \mathrm{Ni}, \mathrm{Pb}$, and $\mathrm{Zn}^{5,15}$, although their translocation capacity is not as high as demonstrated for other known hyperaccumulators. B. juncea is a tolerant plant to heavy metals, grows fast and produces a large amount of above-ground biomass. Due to these characteristics, this species has been the target of several studies to evaluate its phytoremediation potential ${ }^{16}$. In most plants, metals are predominantly accumulated in the roots, but in hyperaccumulators metal concentrations are substantially higher in the aboveground parts ${ }^{1}$. The chelation of heavy metals, especially by phytochelatins, seems to be one of the most important mechanisms for the tolerance of Brassica species. In these plants the role of heavy metal transporters is much clearer and they seem to be of a fundamental importance in the tolerance to various heavy metals ${ }^{16}$. In the presence of metals, there is an increase in ROS generation in plant cells and oxidative damage ${ }^{5}$. Therefore it seems that metal hyperaccumulating plants should have extremely efficient antioxidative and detoxicative defence mechanisms, enabling growth and development in a polluted environment. Due to advances in research on levels of transcripts and metabolites involved in abiotic stress such as heavy metals, it will be possible in the future to establish a clear picture of the tolerance and defence mechanisms used in Brassica species ${ }^{16}$. Plants exposed to heavy metal stress respond by altering their cellular mechanisms and gene expression ${ }^{7}$. Owing to efficient detoxification mechanisms such as glutamylcysteine- $\gamma$ synthetase $(\gamma \mathrm{ECS})$ and glutathione reductase (GR1), plants avoid metal toxicity, but suffer from oxidative stress with increasing stress levels. This is manifested by excessive production of reactive oxygen species (ROS), and increases in the degree of lipid peroxidation and the level of oxidized proteins. Plant cells are equipped with an antioxidant defence system to minimize oxidative stress, such as the antioxidant enzymes: superoxide dismutase (SOD), catalase (CAT) and ascorbate peroxidase (APOX). Most of the available literature data present the results of impact studies on individual trace elements per plant, whereas they often grow in soil containing various metal ions. Therefore, in our study, we used a two-element combinations of metals to assess their net effect on the seedlings of $B$. juncea.

The main objectives of this study were to determine how stress conditions caused by contamination with bimetals in $B$. juncea organs influence (i) the increase in the biomass of mustard seeds, (ii) the accumulation of trace metals and micronutrients, (iii) translocation of metals from roots to above-ground parts, (iv) the level of oxidative stress, (v) the level of transcription of enzymes of the detoxificative and antioxidative system in the first $24 \mathrm{~h}$ of exposure to abiotic stress.

\section{Results}

Levels of metal accumulation. The levels of metal accumulation in the roots, stems, and leaves of B. juncea were determined using the inductively coupled plasma mass spectrometry (ICP-MS), (Fig. 1). The highest accumulation of $\mathrm{Pb}$ was observed in the roots, especially in the case of the $\mathrm{PbZn}$ combination and it reached over $70 \%$ of all metals taken, while to the above-ground parts, $\mathrm{Pb}$ was transported in the amount $-20 \%$ in stems, $6 \%$ in leaves. Cd ions were transported to the above-ground parts in plants treated with $\mathrm{ZnCd}$ the most: roots 39\%, $15 \%$ shoots, and $46 \%$ leaves. An equally high accumulation of $\mathrm{Pb}$ and $\mathrm{Cd}$ metals was observed in the shoots of plants treated with $\mathrm{PbCd}$, amounting to $45 \%$ for $\mathrm{Cd}$ and $39 \%$ for $\mathrm{Pb}$.

Effect of the metal uptake on micronutrient accumulation in plants $B$. juncea. Our research on the effect of treating mustard seedlings with trace metals on the plant's ability to uptake micronutrients yielded results (Fig. 2). We expected that the presence of high concentrations of exogenous metals in the medium would lower the content of copper and zinc. Meanwhile, during the treatment with metals, zinc uptake increases and copper decreases in whole plants, and significant differences are observed at the level of individual organs. Under the tested conditions, there is a clear tendency for microelements to accumulate in the stems, both for $\mathrm{Cu}$ and $\mathrm{Zn}$. This may be partly explained by an increase in apoplastic transport to the conducting bundles and the opening of nonspecific ion channels in the presence of trace element ions competing for specific transporters. The metal accumulation profile is similar in roots and leaves, where the metal uptake into cells from the solutions is observed-soil in the roots and apoplastic transport in leaves. Transport to the conductive bundles requires different transporters (Fig. 3).

Biomass and morphological changes. The highest inhibition of seedling biomass growth was observed for B. juncea plants treated with combinations of $\mathrm{CuCd}, \mathrm{CuZn}$, and $\mathrm{PbCd}$ (Fig. 4). After $96 \mathrm{~h}$ of cultivation, the biomass of seedlings was about $43-59 \%$ lower than at the beginning of cultivation and $68 \%-76 \%$ lighter than in the control plants. The weakest inhibitory effect was observed for the $\mathrm{ZnCd}$-treated seedlings, because after $96 \mathrm{~h}$ of treatment, the seedlings were $38 \%$ heavier than at the beginning of the cultivation and only $20 \%$ lighter than the control plants. We observed morphological changes in the area of the leaf blade, which were manifested by the presence of necrotic spots on the leaves and the inhibition of the growth of the leaf surface in relation to the control seedlings. Moreover, in the case of seedlings treated with $\mathrm{CuZn}$ and $\mathrm{CuCd}$, the leaves were slightly twisted, and with $\mathrm{CuPb}, \mathrm{PbCd}$, and $\mathrm{PbZn}$, there was chlorosis. The $\mathrm{ZnCd}$ combination caused the smallest morphological changes.

Higher levels of $\mathrm{O}_{2}{ }^{-}$were observed in roots exposed to constant bimetal stress than in the above-ground parts, reaching maximum values between the 24 and $72 \mathrm{~h}$ of cultivation (Fig. 5). We observed the highest values of $\mathrm{O}_{2}{ }^{-}$in seedlings treated with the $\mathrm{ZnCd}$ combination, both in the roots and in the above-ground parts. A high level of $\mathrm{O}_{2}{ }^{-}$in mustard roots was also observed for the combination of $\mathrm{CuPb}$ (after $24 \mathrm{~h}$ ) and $\mathrm{PbZn}$ (after $72 \mathrm{~h}$ ). In the above-ground parts, the highest level of $\mathrm{O}_{2}{ }^{-}$was observed after $24 \mathrm{~h}$ especially for $\mathrm{ZnCd}$, and then in the following days of cultivation it decreased by about $50 \%$.

The profile of changes and the level of $\mathrm{H}_{2} \mathrm{O}_{2}$ values were similar in the roots and in the above-ground parts (Fig. 5). High values of $\mathrm{H}_{2} \mathrm{O}_{2}$ were obtained after $24 \mathrm{~h}$ of cultivation in the roots of plants treated with mixtures, 


\section{Accumulation of trace metal}

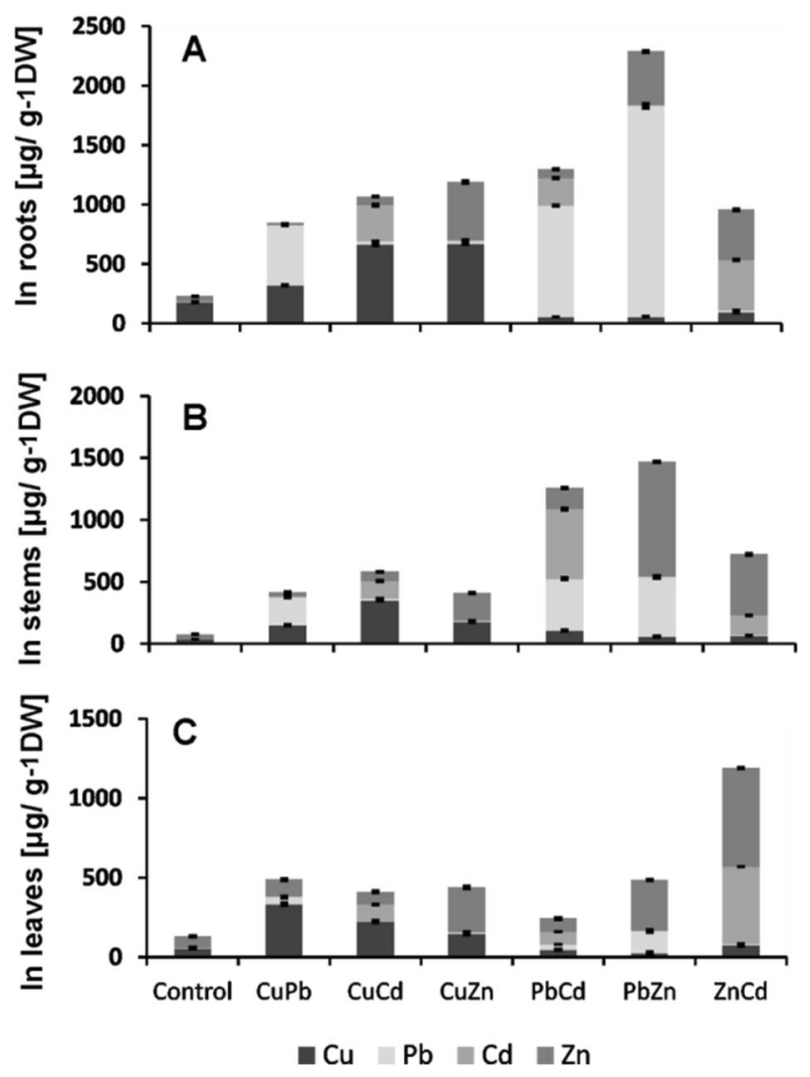

Figure 1. Accumulation of metals: $\mathrm{Pb}, \mathrm{Cu}, \mathrm{Cd}$, and $\mathrm{Zn}$ in the roots $(\mathbf{A})$, stems $(\mathbf{B})$, and leaves $(\mathbf{C})$ of $B$. juncea v. Malopolska seedlings. Plants were grown in Hoagland's medium and treated metal bicombinations: $\mathrm{CuPb}$, $\mathrm{CuCd}, \mathrm{CuZn}, \mathrm{PbCd}, \mathrm{PbZn}$, and $\mathrm{ZnCd}$. Metal solutions $\mathrm{Pb}\left(\mathrm{NO}_{3}\right)_{2}, \mathrm{CuSO}_{4}, \mathrm{CdCl}_{2}$, and $\mathrm{ZnSO}_{4}$ were applied at a $25 \mu \mathrm{M}$ concentration of each. Mean values of three replicates $( \pm \mathrm{SD})$.

especially $\mathrm{CuCd}, \mathrm{ZnCd}$, and $\mathrm{CuPb}$, and they were 2-3 times higher than in control plants. In the above-ground parts, the highest level of $\mathrm{H}_{2} \mathrm{O}_{2}$ was observed for the samples treated with $\mathrm{CuPb}$ after $48 \mathrm{~h}$ and the combinations of $\mathrm{CuCd}$ and $\mathrm{PbZn}$ after $72 \mathrm{~h}$ and they were 3-4 times higher than in the control plants. In the roots, after $96 \mathrm{~h}, \mathrm{a}$ decrease in the level of $\mathrm{H}_{2} \mathrm{O}_{2}$ could be seen, in the above-ground parts after $72 \mathrm{~h}$; however, it remained at a level 2-3 times higher than in control plants until the end of the cultivation in plants exposed to metal combinations.

The profile of changes in $\mathrm{O}_{2}^{--}$and $\mathrm{H}_{2} \mathrm{O}_{2}$ levels observed with the confocal microscope was consistent with the results obtained spectrophotometrically. The most intense DHE fluorescence, indicating the presence of $\mathrm{O}_{2}{ }^{-{ }^{-}}$, was observed in the roots of $\mathrm{B}$. juncea treated with $\mathrm{CuPb}, \mathrm{CuCd}$, and $\mathrm{ZnCd}$, while the highest generation of $\mathrm{H}_{2} \mathrm{O}_{2}$ was observed in the roots exposed to $\mathrm{CuPb}, \mathrm{CuZn}, \mathrm{PbZn}$, and $\mathrm{ZnCd}$ after $24 \mathrm{~h}$ of cultivation (Fig. 6).

Level of protein oxidation. The levels of protein oxidative modification imposed by the bimetal treatment were 2-4 times higher in the roots and the above-ground parts compared to the control plants (Fig. 7). In the roots, the level of oxidized proteins reached its maximum after $48 \mathrm{~h}$, while in the above-ground parts after $72 \mathrm{~h}$ of exposure to combination bimetals.

Levels of gene transcripts. To estimate the changes at the level of transcripts of genes encoding CuZnSOD, MnSOD, yECS, and GR1, we used the electrophoretic separation technique and the CpAtlas program (Fig. 8).

An almost double increase in the expression of the gene encoding CuZnSOD was observed in the roots after 4 and $8 \mathrm{~h}$ for plants treated with the $\mathrm{CuPb}$ combination, while in the above-ground parts, mainly for combinations with $\mathrm{Cu}$, i.e. $\mathrm{CuPb}, \mathrm{CuZn}$ and $\mathrm{CuCd}$, there was an increase of about $50 \%$ after $4 \mathrm{~h}$. In the early hours of the stress factors activity, that is, after 2 and $4 \mathrm{~h}$, no significant changes in the transcription levels of the gene encoding MnSOD in the roots were observed as compared to the control plants. Only after $8 \mathrm{~h}$, an induction of the MnSOD gene expression in the roots by the $\mathrm{ZnPb}$ combination was observed. On the other hand, in the above-ground parts, a significant increase in the level of transcription was noted, over 2 times, for the combination of $\mathrm{CdPb}$ after 4 and $8 \mathrm{~h}$ of cultivation. 


\section{Effect of trace metal treatment on the accumulation of micronutrients $(\mathrm{Cu}, \mathrm{Zn})$ in the tissues of $B$. juncea}

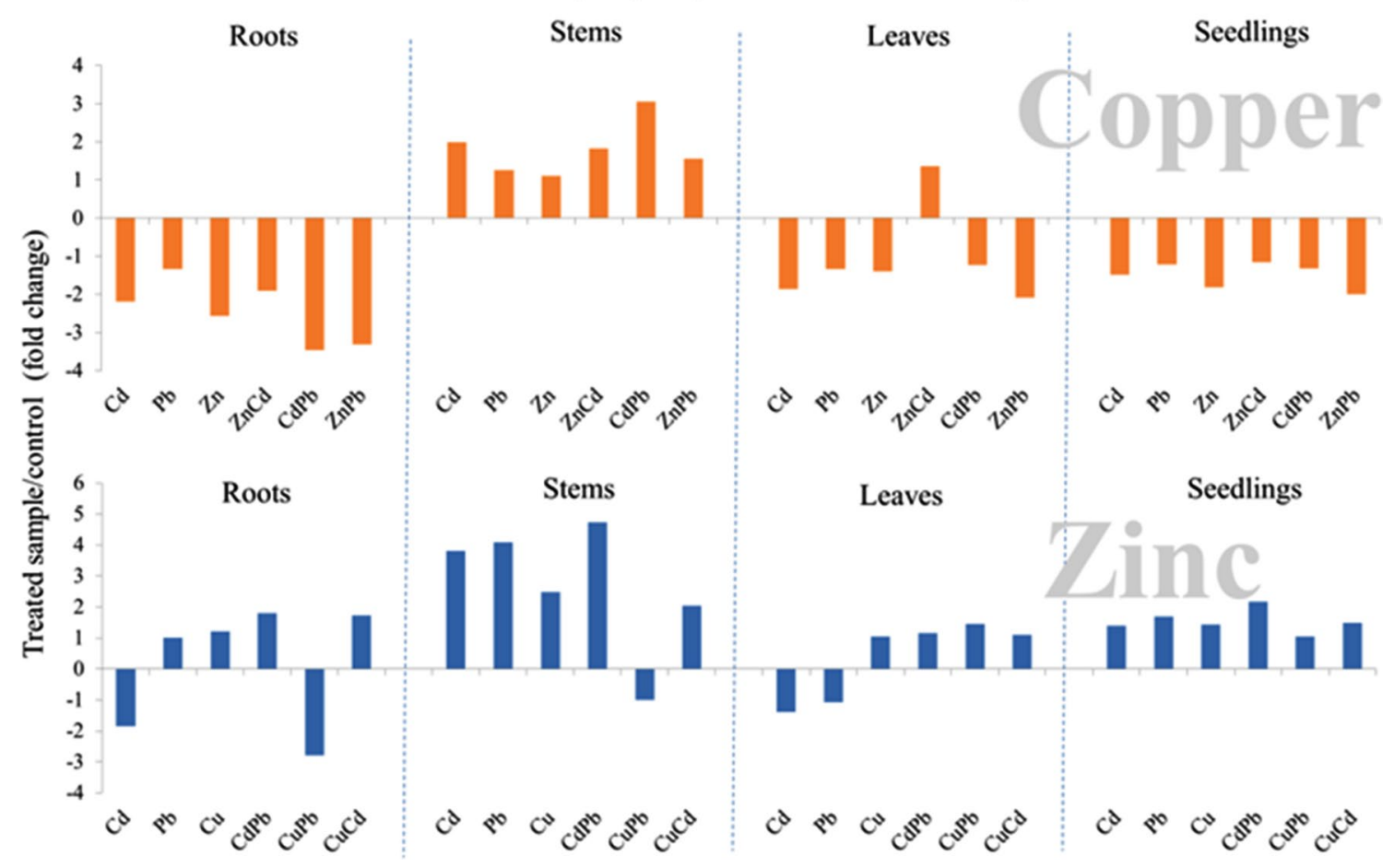

Figure 2. Accumulation of essential microelements: $\mathrm{Cu}, \mathrm{Zn}$ in B. juncea v. Malopolska organs (roots, stems and leaves). Plants were grown in Hoagland's medium and treated with bimetal combinations: $\mathrm{CuPb}, \mathrm{CuCd}$, $\mathrm{CuZn}, \mathrm{PbCd}, \mathrm{PbZn}$, and $\mathrm{ZnCd}$. Metal solutions $\mathrm{Pb}\left(\mathrm{NO}_{3}\right)_{2}, \mathrm{CuSO}_{4}, \mathrm{CdCl}_{2}$, and $\mathrm{ZnSO}_{4}$ were applied at a $25 \mu \mathrm{M}$ concentration of each. Mean values of three replicates $( \pm S D)$.

By analyzing the changes in the expression of the GR1 gene, a clear induction of gene expression in the roots was observed in plants treated with mixtures containing $\mathrm{Pb}$, i.e. $\mathrm{CuPb}, \mathrm{CdPb}$, and $\mathrm{ZnPb}$ at all tested times $(2-5$ times), in the above-ground parts with $\mathrm{CuPb}$ and $\mathrm{ZnPb}$ (2-10 times).

When analyzing the changes in the expression of the gene encoding the $\gamma E C S$ a 2-3 times, an increase in the level of transcription was observed in roots after $4 \mathrm{~h}$ and $8 \mathrm{~h}$ of exposure to combinations of $\mathrm{CuPb}$ and $\mathrm{CuZn}$.

In the above-ground parts, a clear gene induction was observed, expressed by more than a twofold increase in the transcript level after $8 \mathrm{~h}$ for the samples treated with combinations of $\mathrm{CuCd}, \mathrm{CuPb}, \mathrm{ZnPb}, \mathrm{ZnCd}$. Plants treated with $\mathrm{CuCd}, \mathrm{CuPb}, \mathrm{ZnPb}$ still showed a very high level of transcription, three-fivefold also after $24 \mathrm{~h}$.

\section{Discussion}

Abiotic stresses, including the presence of trace metals in soil, are estimated to be the main cause of global crop yield reduction by ca. $70 \%$ and thus are considered a great constraint to crop production ${ }^{5}$. B. juncea is the oldest cultivated crop for eating, oil food, and biodiesel production ${ }^{17}$. Therefore, it is very important to understand its defence mechanisms against the toxic effects of trace metals. Plants, especially hyperaccumulating plants, have developed very efficient defence mechanisms, both in terms of metal detoxification and removing damage resulting from the presence of metals, including oxidative damage ${ }^{18}$. Thus, it is important to learn about these mechanisms and determine which one whether detoxifying or antioxidant, is activated first at the level of transcription of genes encoding suitable enzymes. Understanding these mechanisms will make it possible to determine the role of both the detoxification and antioxidant systems under the conditions of abiotic factors. In our study, we found that in the case of B. juncea v. Malopolska, all the mentioned combinations of metals used in the concentrations of $25 \mu \mathrm{M}$ each displayed moderate phytotoxic properties. The greatest reduction in biomass growth was caused by the mixtures of $\mathrm{CuCd}$, $\mathrm{CuZn}$ and $\mathrm{PbCd}$, only the $\mathrm{ZnCd}$ combination caused no its significant reduction. At the same time, we observed an intense uptake and accumulation of $\mathrm{Cd}$ in the above-ground parts of plants treated with $\mathrm{ZnCd}$. These results demonstrate a synergistic interaction of these metals in $B$. juncea during translocation in shoots. Other researchers have also noted that $B$. juncea accumulates metals such as: $\mathrm{Cd}, \mathrm{As}, \mathrm{Pb}$ and $\mathrm{Cu}$ in the aboveground parts ${ }^{15}$, whereas different authors ${ }^{19}$ reported that $\mathrm{Zn}$ induced a decrease in the $\mathrm{Cd}$ uptake and a simultaneous increase in the $\mathrm{Zn}$ accumulation in tomato plants. This suggested strong competition between $\mathrm{Zn}$ and $\mathrm{Cd}$ for the same membrane transporters. Using the ICP-MS method, we recorded higher translocation and accumulation of $\mathrm{Pb}, \mathrm{Cd}$, and $\mathrm{Zn}$ in the above-ground parts of Brassica juncea than in roots. Other authors ${ }^{20}$ have also noted levels of heavy metals in B. juncea shoots and the order of bioaccumulation was as follows $\mathrm{Cu}>\mathrm{Cd}>\mathrm{Pb}>\mathrm{Cr}$. Similarly, Rajput et al. ${ }^{21}$ found, that the ability to hyperaccumulate different pollutants can be correlated either positively $(\mathrm{Cd}-\mathrm{Zn}, \mathrm{Pb}-\mathrm{Zn}, \mathrm{Co}-\mathrm{Cu}, \mathrm{Cd}-\mathrm{Pb})$ or negatively $(\mathrm{Cu}-\mathrm{PAHs}, \mathrm{Co}-\mathrm{Cd}$, 


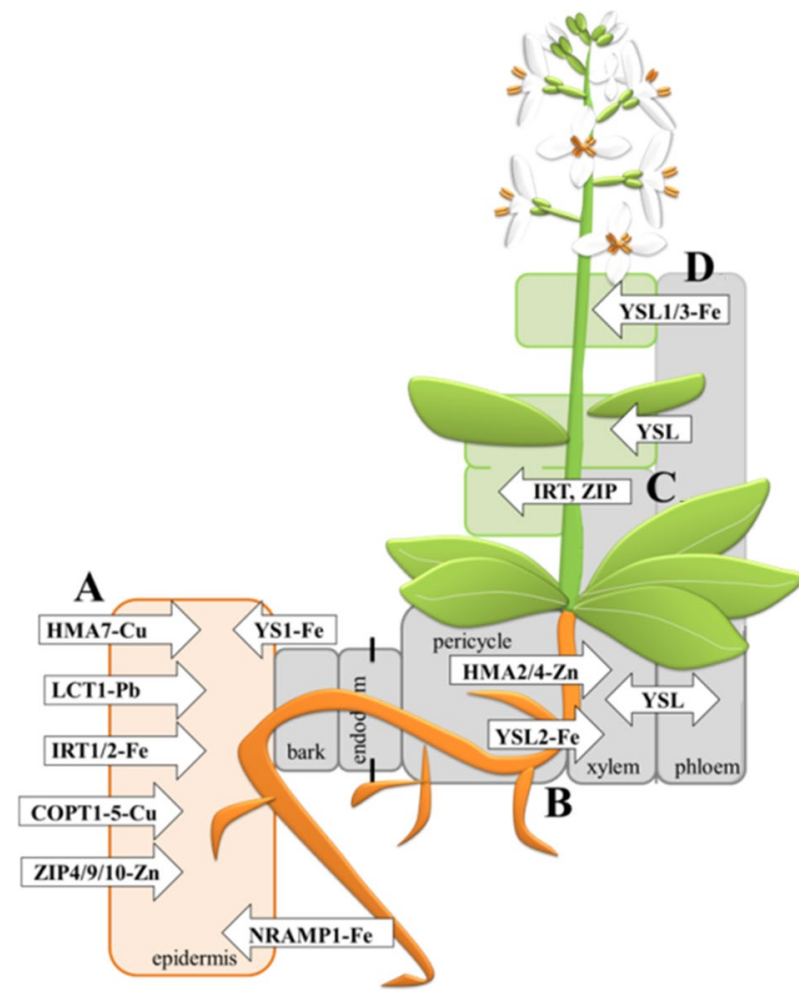

Figure 3. Generic diagram of the localisation of postmembrane trace metal transporters in higher plants. Part (A) uptake of metals to the roots, (B) transport to xylem/phloem, (C) transport to the leaves, (D) transport to the seeds (metals transporters: HMA2/4 for Zn; ITR1/2 for Fe; HMA5 for Cu, ZIP family, LCT1 channels, Nramo family for Fe, Ca and Zn; COPT1 for Cu, YSL family for Fe).

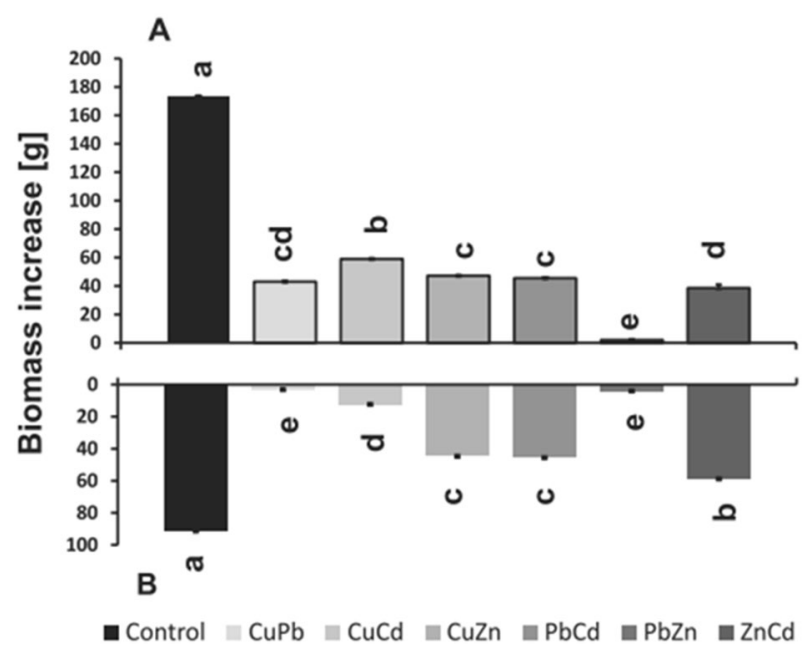

Figure 4. Changes in biomass of $B$. juncea roots and seedlings (A) and roots (B) treated with trace metals: $\mathrm{CuPb}, \mathrm{CuCd}, \mathrm{CuZn}, \mathrm{PbCd}, \mathrm{PbZn}$, and $\mathrm{ZnCd}$ after $96 \mathrm{~h}$ of cultivation. The results are expressed as the mean \pm standard deviation $(n=3)$, with results of Duncan's Test, made separately for $A$ and $B$. Metal solutions $\mathrm{Pb}\left(\mathrm{NO}_{3}\right)_{2}, \mathrm{CuSO}_{4}, \mathrm{CdCl}_{2}$, and $\mathrm{ZnSO}_{4}$ were applied at $25 \mu \mathrm{M}$ concentration of each.

$\mathrm{Co}-\mathrm{PAHs}, \mathrm{Ni}-\mathrm{PAHs}, \mathrm{Cu}-\mathrm{Ni}, \mathrm{Mn}-\mathrm{PAHs}$ ). The authors ${ }^{21}$ suggest that the metals $\mathrm{Cd}, \mathrm{Pb}$ and $\mathrm{Zn}$ are very similar to each other in their soil biochemistry and migration patterns, and hence they can use the same transporters. It was found that $\mathrm{Cd}, \mathrm{Pb}$, and $\mathrm{Zn}$ are carried into vacuoles by the same P-type ATPase HMA3, suggesting that these metals are hyperaccumulated by the same mechanisms ${ }^{21}$. Trace metals can compete with each other for metal transporters, e.g. $\mathrm{Cd}^{2+}$ ions have physicochemical properties similar to essential divalent metal ions and use their transporters (HMA2/4, ZIP4, etc.). This is an example of direct competition between metals for pathways to 

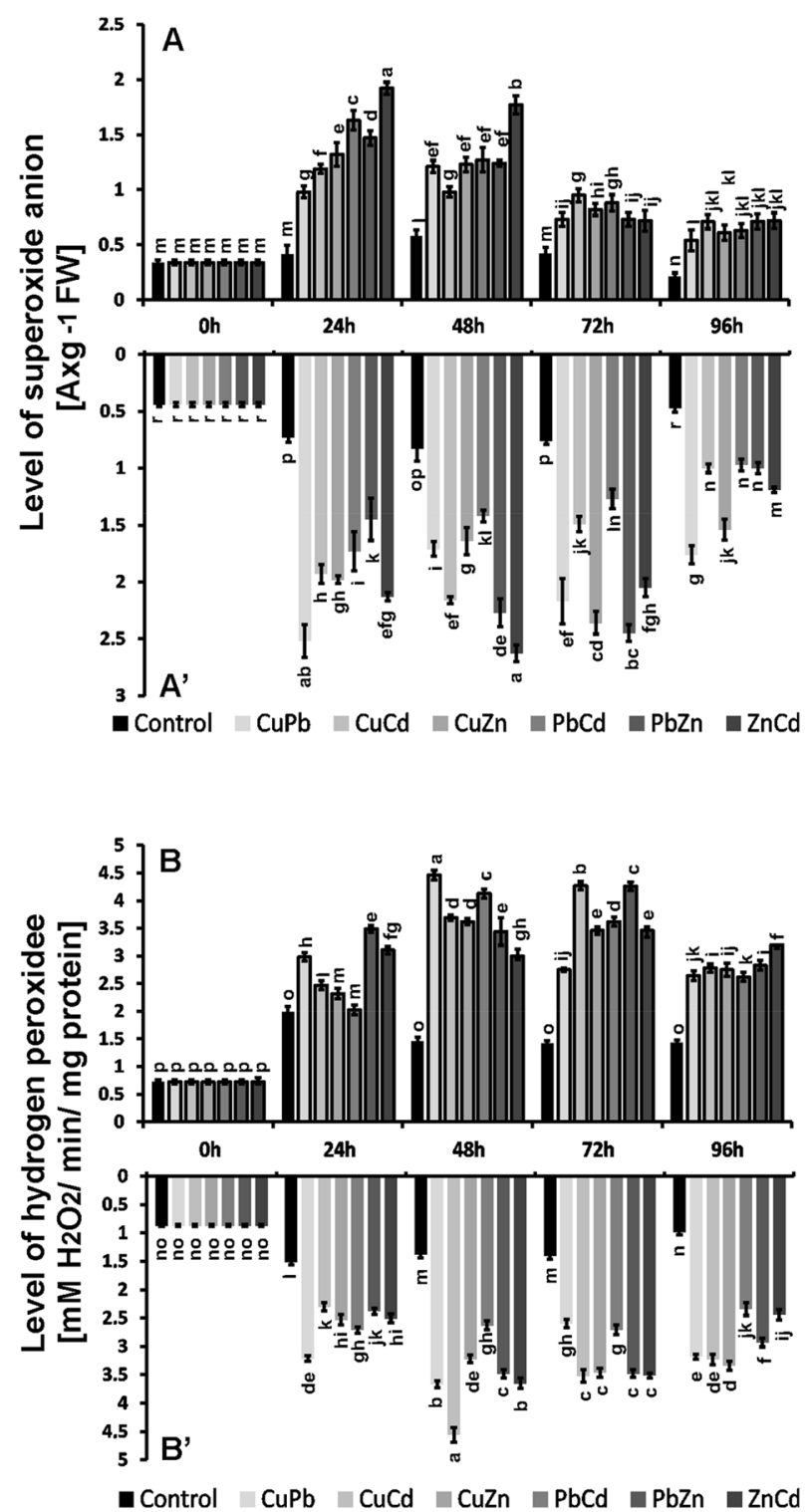

Figure 5. Superoxide anion (A580 $\mathrm{g}^{-1} \mathrm{FW}$; (A)-above-ground part, (A') -root) and hydrogen peroxide (nMol $\mathrm{H}_{2} \mathrm{O}_{2} \times \min ^{-1} \times \mathrm{mg}_{\text {protein }}{ }^{-1}$; (B) - above-ground parts, B'-root) levels in in juncea $\mathrm{v}$. Malopolska seedlings grown in Hoagland's medium and treated with ions in combinations: $\mathrm{CuPb}, \mathrm{CuCd}, \mathrm{CuZn}, \mathrm{PbCd}, \mathrm{PbZn}$, and $\mathrm{ZnCd}$ after $96 \mathrm{~h}$ of cultivation. Metal solutions $\mathrm{Pb}\left(\mathrm{NO}_{3}\right)_{2}, \mathrm{CuSO}_{4}, \mathrm{CdCl}_{2}$, and $\mathrm{ZnSO}_{4}$ were applied at a $25 \mu \mathrm{M}$ concentration of each. Mean values of three replicates $( \pm \mathrm{SD})$, with results of Duncan's Test, made separately for (A) and (B).

enter cells. Lead ions are transported mainly apoplastically or through channels for bivalent ions. Calcium ions enter the plant in a similar way; therefore, the increased concentration of lead ions may destabilize the calcium metabolism ${ }^{1,22,23}$. We observed an increase in zinc uptake and a decrease in copper in individual organs. The inhibition of biomass and plant growth by trace metals may be caused by many factors, such as water stress, which leads to a reduction in stomatal conductivity, lower transpiration and relative water content in leaves s.7. $^{5,}$ Plants, through the root cortex tissues, take metals from the soil solution due to their similarity with the same essential micronutrients such as $\mathrm{Zn}$ or $\mathrm{Cu}$, and then symplastically or apoplastically they pass to the xylem and are transported to the shoots and stored in vacuoles ${ }^{7,20}$. Milner and Kochian ${ }^{24}$ found that $\mathrm{Zn}$ was bound to histidine and organic acids inside the roots and in the free ionic form of $\mathrm{Zn}^{2+}$ in xylem juice. In contrast, the $\mathrm{Zn}$ in shoots was found mainly in combination with organic acids, and only some parts of it were in the free ionic form. This suggests that the metal ions are transported from the roots in the chelated form as free ions and then stored again in the shoots, where they are bound by the chelates ${ }^{9}$. Other authors have also noted that $\mathrm{Zn}$ and, to a lesser extent, $\mathrm{Cd}$ are mobile and can be transferred by phloem to the above-ground parts of plants and accumulate in meristems (root tips, shoot tips, axillary buds) ${ }^{23}$. Israr et al. ${ }^{25}$ concluded that the co-presence of metals $(\mathrm{Pb}+\mathrm{Cu}$, $\mathrm{Pb}+\mathrm{Ni}, \mathrm{Pb}+\mathrm{Zn}, \mathrm{Cu}+\mathrm{Ni}, \mathrm{Cu}+\mathrm{Zn}, \mathrm{Zn}+\mathrm{Ni}, \mathrm{Pb}+\mathrm{Ni}+\mathrm{Cu}+\mathrm{Zn}$ ) results in a greater reduction in plant biomass 


$\begin{array}{lllllll}\text { Control } & \mathrm{CuPb} & \mathrm{CuCd} & \mathrm{CuZn} & \mathrm{PbZn} & \mathrm{PbCd} & \mathrm{ZnCd}\end{array}$

A

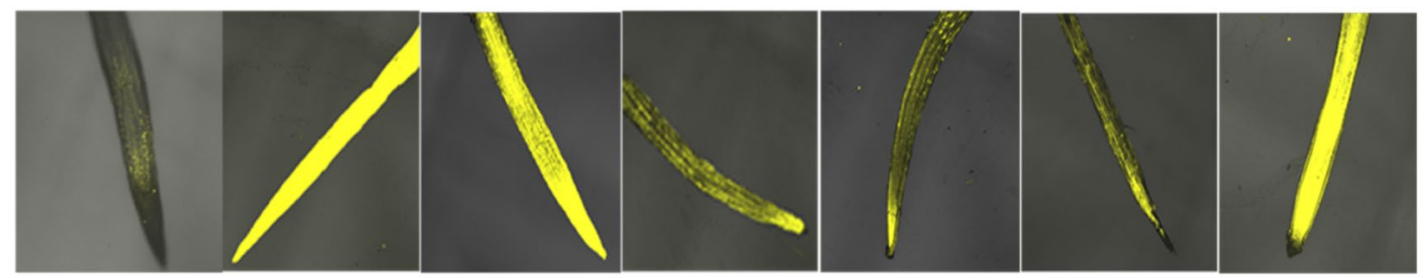

B
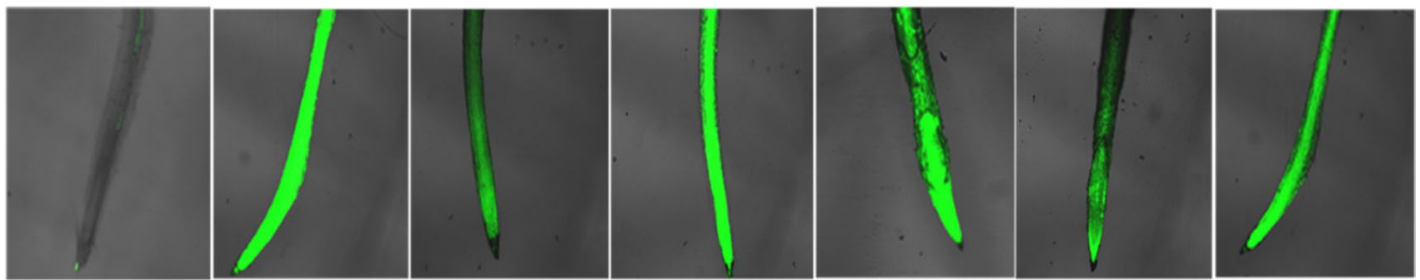

Figure 6. Generating of $\mathrm{O}_{2}{ }^{-}$and $\mathrm{H}_{2} \mathrm{O}_{2}$ in $\mathrm{B}$. juncea v. Malopolska roots using fluorescent microscopy. Plants were grown in Hoagland's medium in the presence bimetals of $25 \mu \mathrm{mol}$ of $\mathrm{Pb}\left(\mathrm{NO}_{3}\right)_{2}, \mathrm{CuSO}_{4}, \mathrm{CdCl}_{2}$, and $\mathrm{ZnSO}_{4}$ in combinations: $\mathrm{CuPb}, \mathrm{CuCd}, \mathrm{CuZn}, \mathrm{PbCd}, \mathrm{PbZn}$, and $\mathrm{ZnCd}$ for $24 \mathrm{~h}$. The roots of treated plants and control stained with DHE for $12 \mathrm{~h}(\mathbf{A})$ and DCFH-DA for $4 \mathrm{~h}(\mathbf{B})$.

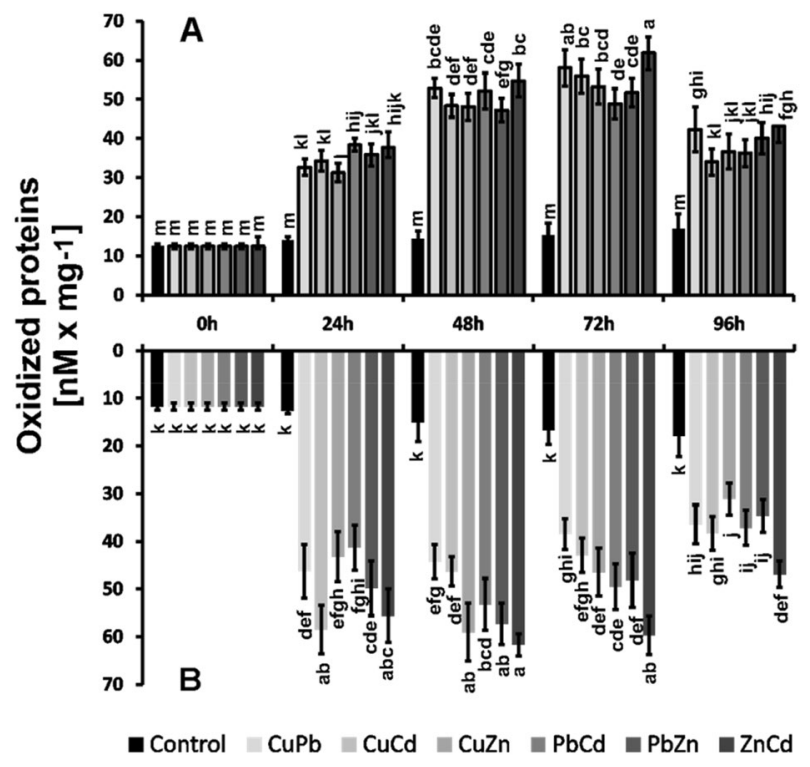

Figure 7. Oxidized protein level above-ground parts (A) and roots (B) of B. juncea v. Malopolska seedlings grown in Hoagland's medium and treated with ions in combinations: $\mathrm{CuPb}, \mathrm{CuCd}, \mathrm{CuZn}, \mathrm{PbCd}, \mathrm{PbZn}$, and $\mathrm{ZnCd}$ after $96 \mathrm{~h}$ of cultivation. Metal solutions $\mathrm{Pb}\left(\mathrm{NO}_{3) 2}, \mathrm{CuSO}_{4}, \mathrm{CdCl}_{2}\right.$, and $\mathrm{ZnSO}_{4}$ were applied at a $25 \mu \mathrm{M}$ concentration of each. Mean values of three replicates $( \pm \mathrm{SD})$, with results of Duncan's Test, made separately for (A) and (B).

than exposure to single metals because of the occurrence of a synergistic or additive response. We observed the accumulation of the metals $\mathrm{Cd}, \mathrm{Zn}$, and $\mathrm{Pb}$ in the above-ground parts of plants in an amount $50 \%$ greater than in the roots. These results indicate an increase in apoplastic transport to the conducting bundles and the opening of nonspecific ion channels in the presence of trace element ions competing for specific transporters. There was a synergistic response between metals in the combinations $\mathrm{PbZn}$ and $\mathrm{ZnCd}$, resulting in an increased accumulation of the two metals in the above-ground parts. B. juncea is a good accumulator of trace metals, especially Cd and could be used for the remediation of $\mathrm{Cd}$ from contaminated soils, because of its ability to translocate large amounts of this metal into its stems and leaves ${ }^{15}$. Trace metals can cause plant growth reduction by decreasing photosynthetic rates, as they disturb mineral nutrition and water balance, change hormonal status, and affect the membrane structure and permeability and chlorophyll content ${ }^{26,27}$. We noted that the presence of other metals in the medium changes the mineral balance of the whole B. juncea plant. Heavy metals may cause severe toxicity in plants by disturbing essential groups such as - $\mathrm{SH}$ of enzymes leading to their inactivation, destroying 


\section{Changes in transcriptional level in $B$. juncea root}
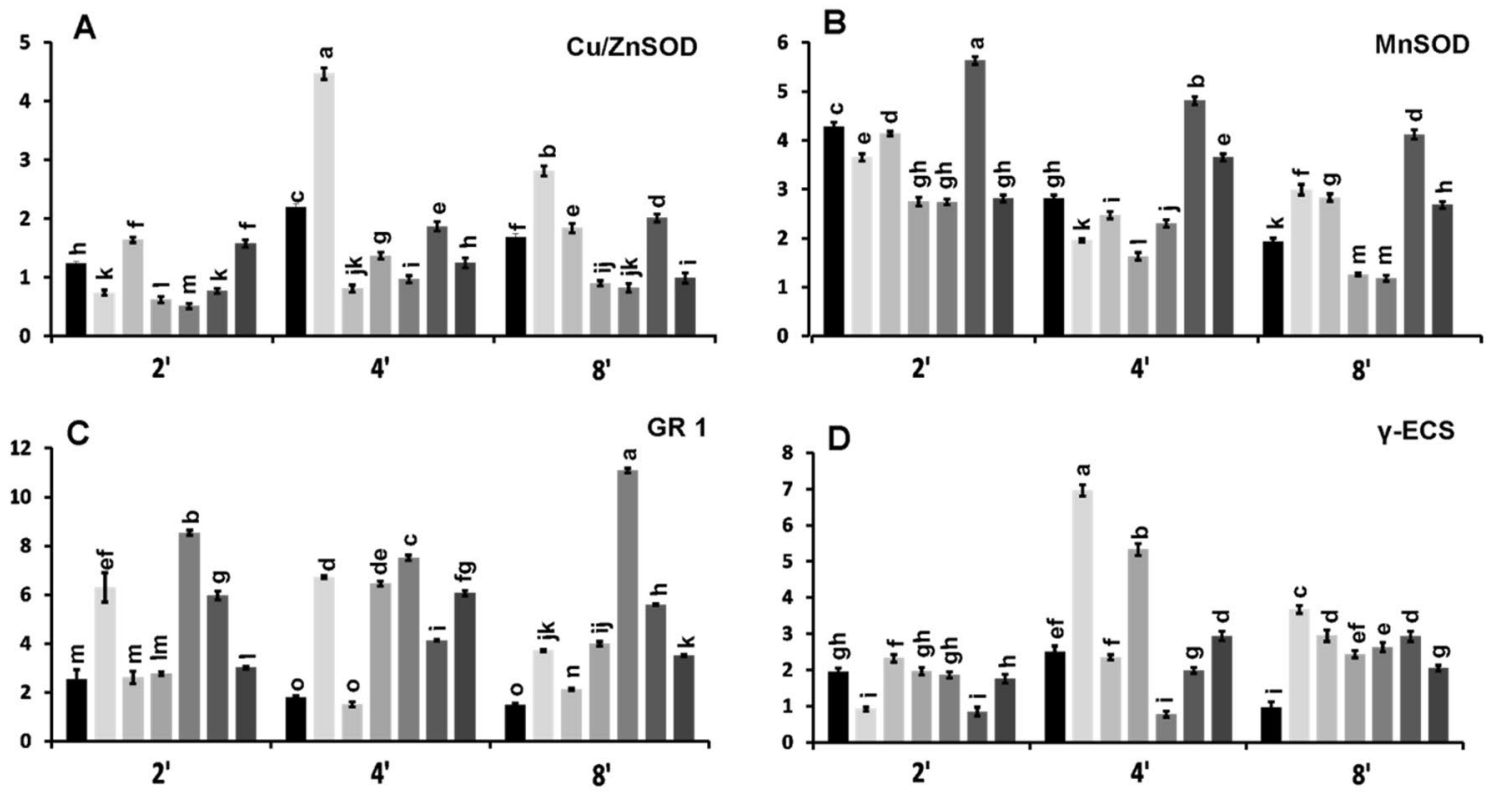

Exposition time [h]

aControl $\square$ CuPb $\square$ CuCd $\square$ CuZn $\square \mathrm{PbCd} \square \mathrm{PbZn} \square \mathrm{ZnCd}$

Changes in transcriptional level in $B$. juncea shoot
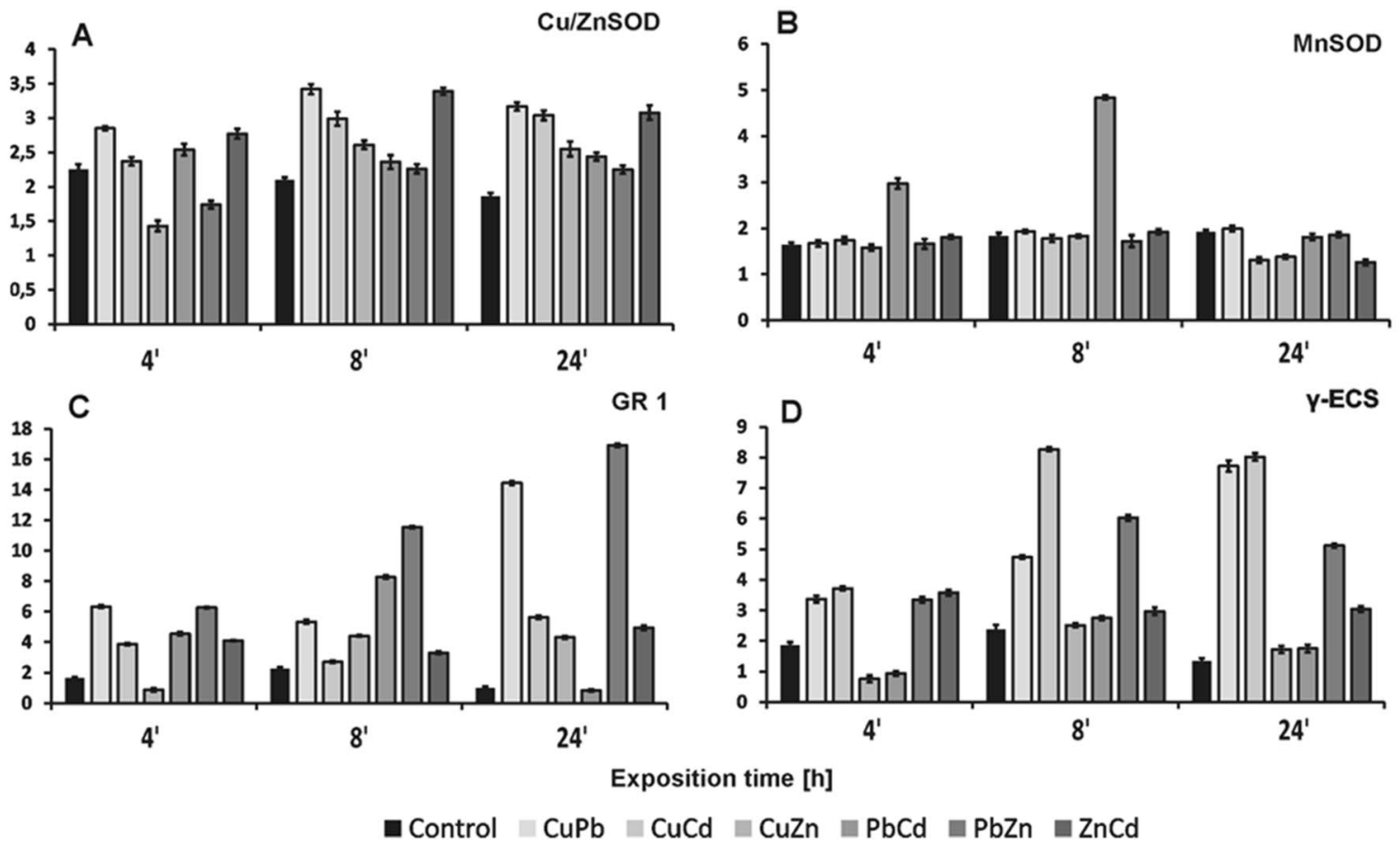

Figure 8. Transcriptional levels of genes encoding antioxidative ( $\mathrm{CuZnSOS}-\mathbf{A}, \mathrm{MnSOD}-\mathbf{B})$ and detoxitative $(\mathrm{GR} 1-\mathrm{C}, \gamma \mathrm{ECS}-\mathrm{D})$ enzymes in roots and shoots of $B$. juncea v. Malopolska seedlings. Plants were grown in Hoagland's medium and treated with bimetals combinations: $\mathrm{CuPb}, \mathrm{CuCd}, \mathrm{CuZn}, \mathrm{PbZn}, \mathrm{PbCd}$, and $\mathrm{ZnCd}$. Metal solutions $\mathrm{Pb}\left(\mathrm{NO}_{3}\right)_{2}, \mathrm{CuSO}_{4}, \mathrm{CdCl}_{2}$, and $\mathrm{ZnSO}_{4}$ were applied of each at a $25 \mu \mathrm{Mol}$ concentration.

Enzymes chosen for the experiment were amplified using semi-quantitative RT-PCR. Primers were designed for Arabidopsis thaliana genes: CSD1 for CuZnSOD, MSD1 for MnSOD, GR1 for GR, and $\gamma \mathrm{ECS}$. 
the integrity of important biomolecules, modifying some macromolecules, replacing essential metal ions from structural formulae of biomolecules, and enhancing the generation of ROS 7,25 .

We observed a significant increase in ROS levels compared to the control plants in all plants treated with the combination of heavy metals, both in the roots and in the aerial parts. The highest values were observed in the organs of plants treated with $\mathrm{ZnCd}, \mathrm{CuPb}, \mathrm{CuCd}$ and $\mathrm{PbZn}$. Therefore, it can be concluded that the most prooxidative are the combinations containing the metals $\mathrm{Cu}$ and $\mathrm{Zn}$.

Toxic metals/metalloids are categorized into redox-active $(\mathrm{Fe}, \mathrm{Cu}, \mathrm{Cr}$, etc.) and redox inactive $(\mathrm{Cd}, \mathrm{Pb}, \mathrm{Zn}$, $\mathrm{Ni}, \mathrm{Al}$, etc.). Metals with higher redox potential than biological molecules (such as $\mathrm{Fe}^{2+}$ and $\mathrm{Cu}^{2+}$ ) participate in biological redox reactions and ultimately induced the ROS directly through Haber-Weiss and Fenton reactions. Other metals/metalloids such as $\mathrm{Cd}, \mathrm{Pb}, \mathrm{Al}, \mathrm{Ni}, \mathrm{Zn}$, etc. cause the ROS generation by impairing the antioxidant defence system (mainly glutathione pool), inducing NADPH oxidase, displacing obligatory cations from binding sites of enzymes and activating the Ca-dependent system ${ }^{28,29}$. Other authors have also reported higher $\mathrm{H}_{2} \mathrm{O}_{2}$ production in $B$. juncea: under the influence of $\mathrm{Cd}$ it was twofold higher after 7 days ${ }^{18}$, for $\mathrm{Cr}, \mathrm{Si}$ and $\mathrm{Cr}+\mathrm{Si}$ it was about 1.5-fold higher ${ }^{30}$, for Cd about tenfold after 5 days $^{31}$ and for As about 2 -fold higher ${ }^{32}$. Also, an over threefold increase in $\mathrm{O}_{2}{ }^{-}$was observed in 10-day-old $B$. juncea seedlings treated with $\mathrm{Pb}$, and with $\mathrm{Cd}$ over twofold ${ }^{33}$. Similarly, a two-fold increase in $\mathrm{O}_{2} \cdot{ }^{-}$and $\mathrm{H}_{2} \mathrm{O}_{2}$ was observed in $B$. juncea seedlings treated with Cd at a concentration of $100 \mathrm{mg} / \mathrm{kg}$ for 45 and 60 days ${ }^{34}$. The fluorescence signal indicating the presence of $\mathrm{O}_{2}{ }^{-{ }^{-}}$and $\mathrm{H}_{2} \mathrm{O}_{2}$ was observed mainly in the meristematic and elongation zones of $B$. juncea roots, which was also confirmed by other authors in $B$. juncea roots exposed to $50 \mu \mathrm{M} \mathrm{Cu}^{35}$. This is probably due to the fact that these zones are most exposed to the toxic effects of metals. An increasing histochemical detection of $\mathrm{O}_{2}{ }^{-{ }^{-}}$and $\mathrm{H}_{2} \mathrm{O}_{2}$ was observed in the leaves of $B$. juncea seedlings treated with $\mathrm{Cd}^{36}$.

The increase in ROS in the roots and above-ground parts of $B$. juncea resulted in an oxidative stress condition. Under these conditions, pro-oxidative-antioxidant reactions towards oxidation are disturbed ${ }^{37}$. Consequently, this led to a two-fourfold increase in the level of oxidized proteins in B. juncea organs. ROS plays a key role as a signaling molecule in plants and controls the physiological functions of plants under stress. Therefore, the balance between ROS production and their elimination is of great importance for the proper functioning of plant cells ${ }^{28}$.

The rapid increase in oxidative stress conditions in cells requires the rapid activation of the antioxidant and the detoxification system, both at the level of activity and the expression of key enzyme genes. In our study, we observed differences in the induction of gene expression encoding enzymes depending on exposure time and metal combination. On the basis of our research, induction of gene expression was observed: CuZnSOD mainly by combinations with copper, MnSOD mainly by combinations of PbZn, and GR1, and yECS mainly by combination containing $\mathrm{Cu}$ and $\mathrm{Pb}$ ions. Other authors have also ${ }^{38}$ observed an increase in the transcript amounts of $\gamma$-glutamylcysteine synthetase ( $\gamma$-ECS), an enzyme which catalyses the first step of the glutathione (GSH) synthesis, in $B$. juncea plants under Cu stress. For the genes encoding CuZnSOD, GR1 and y-ECS, there was a greater increase in expression in shoots than in roots. This is probably due to the fact that hyperaccumulators are characterized by a higher accumulation of metals in the above-ground parts of the plants. Plants respond to abiotic factors such as heavy metal stress via immediate change in expression of the stress responsive genes at the transcriptional level ${ }^{39}$. The superoxide radical dismutation reaction is one of the first stages of the cascade of processes leading to the detoxification of $\operatorname{ROS}^{5,37}$. Therefore, the induction of genes encoding SOD, including $\mathrm{CuZnSOD}$ and MnSOD, is a very important factor determining the acclimatization of plants to stressful conditions $s^{5,40}$. However, it seems that $B$. juncea plants, which are hyperaccumulators, tolerate oxidative stress conditions well and do not show the need to induce the antioxidant system at the level of protein transcription. Our results indicate that during the first $24 \mathrm{~h}$ of exposure to metal stress, gene expression is induced, mainly the detoxification enzymes GR1 and yECS. Naturally, under metal stress, ROS are generated-hence the need to induce the expression of genes encoding antioxidant proteins. In our previous research, we observed an increase in the level of the gene encoding CuZnSOD in B. juncea plants treated with single copper, zinc, and lead ions the highest after $4 \mathrm{~h}$ in the roots and after $8 \mathrm{~h}$ in the above-ground parts, and MnSOD in the roots after $8 \mathrm{~h}$ exposure to $\mathrm{Zn}$ and $\mathrm{Pb}$ ions ${ }^{5}$. Other authors ${ }^{41}$ using microarray results found that the $\mathrm{Cd}$ stress response in Brassica nigra plants after $72 \mathrm{~h}$ was much stronger in roots ( 88 genes showing increased or decreased mRNA levels) than in shoots (24 responding genes). They detected an increase in the expression of genes encoding y-ECS and PCS (phytochelatin synthase) in the roots and leaves of the tolerant and nontolerant ecotypes of B. nigra. CuZn superoxide dismutase (CSD1), catalase (CAT3 and CAT1), and peroxidase genes were downregulated, indicating regulation of hydrogen peroxide contents. Also, a significant effect of metal Cd stress on the induction of gene expression related to GSH (glutathione) metabolism in B. juncea using Comparative Transcriptome Profiling was noted by Thakur et al. ${ }^{42}$. These authors observed that among the transcripts mapping to GSH metabolism, the gene expression of a total of ten important components including glutathione S-transferase (GST), glutathione synthase (GSS), and gamma-glutamyltranspeptidase (GGT) was found to be modulated by cadmium. A total of 66 different transcripts encoding GST were found to be significantly upregulated. Additionally, other authors ${ }^{43}$ observed in Brassica chinensis L. cultivar Aikangqing (a Cd-tolerant cultivar) an increase in expression of genes encoding $y$-ECS and GR in shoots after exposure to Cd ions. The authors postulate that in response to Cd stress in plants, there is overexpression of enzymes related to sulphur assimilation, thus increasing the tolerance to heavy metals. The addition of $S$ in the experiment identified an increase in expression of defence enzyme genes. $S$ uptake results in the initial formation of the first solid product, cysteine, which is needed for the synthesis of GSH, a low molecular weight antioxidant. GSH, in turn, is involved in both the ASA-GSH cycle and the biosynthesis of phytochelatins to regulate heavy metal detoxification. Therefore, whether the regulation of $\mathrm{S}$ assimilation related to heavy metal toxicities is essential in plant defence mechanisms still requires research ${ }^{42,43}$. Undoubtedly, however, exposure to toxic metal ions or high concentrations of non-toxic ions triggers stress reactions in plants that require adaptation at various levels: structural, physiological, biochemical and molecular. Based on our present results, it seems that triggering defence mechanisms related to detoxification of heavy metals is 
crucial for $B$. juncea plants. However, we have previously reported ${ }^{6}$ that plants are not adequately protected by the detoxification system because trace metals penetrate areas with high metabolic activity, such as the cytoplasm, mitochondria, or cell membrane-hence, the strong need for the mutual cooperation of two defence systems of plants: detoxicative and antioxidative.

\section{Materials and methods}

Plant material. The plant material was grown according to Malecka et al. ${ }^{5}$. Seeds of B. juncea v. Malopolska were grown in Petri dishes for 7 days under optimal conditions. Next, young seedlings were cultivated hydroponically on Hoagland's medium for one week in a growth room with a 16/8 h photoperiod, day/night at room temperature and light intensity of $82 \mu \mathrm{mol} \mathrm{m}{ }^{2} \mathrm{~s}^{-1}$. After that, we changed the medium to $100 \times$-diluted Hoagland's solutions. Next, on 14 day old seedlings a trace metal solution was applied in combination: $\mathrm{CuPb}, \mathrm{CuCd}, \mathrm{CuZn}$, $\mathrm{PbCu}, \mathrm{PbCd}, \mathrm{Pb} \mathrm{Zn}$, and $\mathrm{ZnCd}$ at a concentration of $25 \mu \mathrm{M}$ of each. We used a solution of $\mathrm{Pb}\left(\mathrm{NO}_{3}\right)_{2}, \mathrm{CuSO}_{4}$, $\mathrm{CdCl}_{2}, \mathrm{ZnSO}_{4}$ in the cultivation. For our studies, we chose the concentration and $25 \mu \mathrm{M}$ because according to our earlier experiments ${ }^{1}$, these are the concentrations at which metals, both essential and non-essential, cause negative changes in Brassica plants, but are not lethal. The roots and shoots of B. juncea were cut off after 0 , $24,48,72$, and $96 \mathrm{~h}$ of cultivation. To eliminate trace elements adsorbed at the root surface, they were dipped sequentially in cold solutions of $10 \mathrm{mM} \mathrm{CaCl}_{2}$ and $10 \mathrm{mM}$ EDTA for $5 \mathrm{~min}$ each. Next, roots and shoots were rinsed three times with distilled water, frozen in liquid nitrogen, and stored at $-80^{\circ} \mathrm{C}$ until the molecular analysis. All other experiments were performed on a freshly harvested plant material.

Biomass increase. The changes in fresh biomass of $B$. juncea seedlings: control and treated with bimetal combinations: $\mathrm{CuPb}, \mathrm{CuCd}, \mathrm{CuZn}, \mathrm{PbCu}, \mathrm{PbCd}, \mathrm{Pb} \mathrm{Zn}$, and $\mathrm{ZnCd}$ were measured using the Radwag scale after $0,24,28,72$ and $96 \mathrm{~h}$ of cultivation.

Accumulation of trace elements. Roots, stems, and leaves of $B$. juncea were collected after $72 \mathrm{~h}$ of treatment with trace metals. Plant samples were rinsed with distilled water, dried at $70 \pm 2{ }^{\circ} \mathrm{C}$, and milled. Next, the dried samples were digested in close microwave digestion oven Ethos One (Milestone S.r.l., Sorisole BG, Italy). Digestion was carried out as follows: $300 \mathrm{mg}$ of dry samples were accurately weighed into the microwave vessels and then $3 \mathrm{ml}$ of $65 \% \mathrm{HNO}_{3}$ and $1 \mathrm{~mL}$ of $30 \% \mathrm{H}_{2} \mathrm{O}_{2}$ were added. After that, samples were transferred to $10 \mathrm{~mL}$ flasks filled with deionized water. Digested samples were quantitatively transferred into polypropylene tubes and diluted with demineralized water (Direct-Q 3UV, Merck, Darmstadt, Germany). The determination of trace metal accumulation was performed using SN-ICP-MS (solution nebulisation inductively coupled plasma mass spectrometry) model Elan DRC II, (PerkinElmer Sciex, Toronto, ON, Canada). More detailed information about the ICP-MS operation conditions, settings, and quality assurance is provided in Konkolewska et al. ${ }^{10}$.

The validity of the analytical method was assessed by analyzing the certified reference material NIST SRM 1570a Trace elements in Spinach Leaves (National Institute of Standards and Technology, Standard Reference Material, Gaithersburg, MD, USA) 10.

Measurements of the level of reactive oxygen species. Superoxide anion content was determined according to Doke ${ }^{44}$ at $580 \mathrm{~nm}$. The plant roots and above-ground parts $(0.5 \mathrm{~g})$ were placed in the test tubes and filled with $7 \mathrm{~mL}$ of mixture containing $50 \mathrm{mM}$ phosphate buffer ( $\mathrm{pH} 7.8$ ), 0.05\% NBT (nitro blue tetrazolium) and $10 \mathrm{mM}$ of $\mathrm{NaN}_{3}$. Next, the test tubes were incubated in the dark for $5 \mathrm{~min}$, and then $2 \mathrm{~mL}$ of the solution were taken from the tubes heated at $85^{\circ} \mathrm{C}$ for $10-15 \mathrm{~min}$, cooled in the ice for $5 \mathrm{~min}$ and the absorbance was measured spectrophotometrically (SHIMADZU UV-1800, Japan) at $580 \mathrm{~nm}$ against the control.

Hydrogen peroxide content was determined according to Patterson et al. ${ }^{45}$. The plant roots and above-ground parts were homogenized in 5\% TCA (Trichloroacetic acid). The homogenate was centrifuged twice at $13,000 \mathrm{~g}$ for $20 \mathrm{~min}$. The level of hydrogen peroxide was determined in the supernatant by the spectrophotometric method at $508 \mathrm{~nm}$. The reaction mixture contained: $50 \mathrm{mM}$ phosphate buffer $(\mathrm{pH} 8.4)$, reagent containing $0.6 \mathrm{mM} \mathrm{4-(-2}$ pyridylazo) resorcinol, $0.6 \mathrm{mM}$ potassium-titanium oxalate in (1:1). The corresponding concentration of $\mathrm{H}_{2} \mathrm{O}_{2}$ was determined against the standard curve of $\mathrm{H}_{2} \mathrm{O}_{2}$.

In situ detection of superoxide anion and hydrogen peroxide. The roots from plants exposed to metals $\mathrm{Pb}\left(\mathrm{NO}_{3}\right)_{2}, \mathrm{CuSO}_{4}, \mathrm{CdCl}_{2}$, and $\mathrm{ZnSO}_{4}$ in combinations: $\mathrm{CuPb}, \mathrm{CuCd}, \mathrm{CuZn}, \mathrm{PbCd}, \mathrm{PbZn}$, and $\mathrm{ZnCd}$ for $24 \mathrm{~h}$ and control were cut and submerged for $12 \mathrm{~h}$ in $100 \mu \mathrm{M}$ of $\mathrm{CaCl}_{2}$ containing $20 \mu \mathrm{M}$ of dihydroethidium (DHE, pH 4.75; samples for superoxide anion radicals) according to Yamamoto et al. ${ }^{46}$ or $4 \mu \mathrm{M}$ dichlorodihydrofluorescein diacetate (DCFH-DA) (samples for hydrogen peroxide) in $5 \mathrm{mM}$ dimethyl sulfoxide (DMSO) according to Afzal et al. ${ }^{47}$. After rinsing with $100 \mu \mathrm{M}$ of $\mathrm{CaCl}_{2}$ or $50 \mathrm{mM}$ phosphate buffer (pH 7.4), the roots were observed with a confocal microscope (Zeiss LSM 510, Axiovert 200 M, Jena, Germany) equipped with no. 10 filter set (excitation $450-490 \mathrm{~nm}$, emission $520 \mathrm{~nm}$ or more).

Determination of the level of protein oxidation. The method of Levine et al. was used to determine the level of oxidized proteins ${ }^{48}$. Roots and above-ground parts $(0.5 \mathrm{~g})$ were incubated with isolation buffer containing 0.1 M Na phosphate buffer, $0.2 \%(\mathrm{v} / \mathrm{v})$ Triton X-100, 1 mM EDTA and $1 \mathrm{mM}$ PMSF. After centrifugation at $13,000 \times g$ for $15 \mathrm{~min}$, supernatants $(200 \mu \mathrm{l})$ were mixed with $300 \mu \mathrm{l}$ of $10 \mathrm{mM} \mathrm{DNPH}$ in $2 \mathrm{M} \mathrm{HCl}$. The blank was incubated in $2 \mathrm{M} \mathrm{HCl}$. After $1 \mathrm{~h}$ of incubation at room temperature, the proteins were precipitated with $10 \%$ $(\mathrm{w} / \mathrm{v})$ trichloroacetic acid (TCA) and the pellets were washed three times with $500 \mu \mathrm{l}$ of ethanol / ethyl acetate (1: 1). The pellets were finally dissolved in $6 \mathrm{M}$ guanidine hydrochloride in $20 \mathrm{mM}$ potassium phosphate buffer ( $\mathrm{pH}$ 


\begin{tabular}{|l|l|l|l|}
\hline GENE & PRIMER Forward & PRIMER Reverse & Gene accession number \\
\hline TUB1 & GTGATTGCTTGCAGGGTTTT & CAGAATACGGAAGCAAATGTCA & X54844.1 \\
\hline GR1 & AGGGTTGGAGAATGTTGGTG & CAATAGGTGGCTGGGAGAAA & X98274.1 \\
\hline CSD1 & GGAACTGCCACCTTCACAAT & CGTTTTCAACCACGTCCTCT & U30841.1 \\
\hline MSD1 & CCTTGCTCCTGTCAAGGAAG & TTCAGATAATCCGGCCTCAC & M63003.1 \\
\hline $\boldsymbol{\gamma}$-ECS: & TGTGGCTGAAGATGTCCTGA & CACACATCGAAATCGTCCAG & AF128455.1 \\
\hline
\end{tabular}

Table 1. The primers used for $\mathrm{qPCR}$.

2.3) and the absorption was measured at $370 \mathrm{~nm}$. The carbonyl content was calculated from the molar absorption coefficient of the aliphatic hydrazones, $22,000 \mathrm{~m}-1 \mathrm{~cm}^{-1}$.

Protein quantification. Total soluble protein contents were determined according to Bradford ${ }^{49}$, using the Bio-Rad assay kit with bovine serum albumin as a calibration standard.

Isolation of total RNA and RT-PCR. Isolation of Total RNA and RT-PCR was performed using the method described by Małecka et al. ${ }^{5}$. Roots and above-ground parts $(100 \mathrm{mg})$ of $B$. juncea plants in the presence of trace metals and under control conditions were collected for total RNA isolation. The RNA was isolated with TRIzol reagent and tested spectrophotometrically for purity at 260 and $280 \mathrm{~nm}$. Then, RNA was reversetranscribed with oligo (dT) primers using the RevertAid Reverse Transcriptase Kit (Thermo Science, Lithuania, European Union) after DNA was treated with DNase I (Thermo Science).

The primers used for qPCR are listed in Table 1.

As a reference gene, the gene encoding tubulin was used. PCRs were performed with 28 (BjGR1), 30 (BJMnSOD), and 34 (BjCuZnSOD and Bj $\gamma$-ECS) cycles of denaturation, $95^{\circ} \mathrm{C}$ for $30 \mathrm{~s}$; annealing primers, $53^{\circ} \mathrm{C}$ for $30 \mathrm{~s}$; and elongation, $72^{\circ} \mathrm{C}$ for $30 \mathrm{~s}$ using a 1:100 diluted cDNA template and REDAllegroTaq DNA Polymerase (Novazym, Poznań, Poland). PCR products were separated by electrophoresis on a $1.3 \%$ agarose gel with ethidium bromide in TBE (445 mM Tris-HCL; $445 \mathrm{mM}$ boric acid; $10 \mathrm{mM}$ EDTA; pH 8.0), visualized under UV light and photographed using the Photo Print 215SD V.99 Vilber Lourmat Set. CP Atlas 2.0 were used for densitometric analysis of relative gene expression.

Statistical analyses. All experiments were performed in three biological and technical replicates. Calculated the mean values \pm SD are provided in figures. Obtained the data were analysed statistically using IBM SPSS Statistics (Version 22 for Windows). Significant differences between treatments were analysed using ANOVA, assuming $\mathrm{p}<0.05$ as the significance threshold.

Statement. In this study we used B. juncea seeds from the Palikije Plant Breeding Station in Poland and our experimental research on plants was complied with institutional, national, or international guidelines.

\section{Conclusions}

The current study demonstrates the influence of $\mathrm{Pb}, \mathrm{Cu}, \mathrm{Cd}$, and $\mathrm{Zn}$ in binary combinations on the metal uptake, biomass growth, level of oxidative stress, and the level of transcriptions of detoxicative and antioxidative enzyme systems of $B$. juncea. Plants accumulated high amounts of trace metals in the above-ground parts, especially Cd using combination of $\mathrm{ZnCd}$. The presence of metals resulted in a considerable reduction in $B$. juncea biomass; the highest reduction was caused by binary combinations containing $\mathrm{Cu}$ and $\mathrm{PbCd}$. Trace metals lead to the production of $\mathrm{O}_{2}{ }^{-}$and $\mathrm{H}_{2} \mathrm{O}_{2}$ and increase the level of oxidized proteins. We noticed that under the conditions of metal stress, transcript level of enzymes: yECS and GR, which are associated with metal detoxification, increase, especially in shoots. No significant differences in the levels of CuZnSOD and MnSOD transcripts both in roots and in shoots were observed. The obtained results indicate that in the organs of B. juncea v. Malopolska, in the first hours of stress, the expression of genes encoding proteins related to the detoxicative system is induced.

Received: 18 May 2021; Accepted: 1 November 2021

Published online: 16 November 2021

\section{References}

1. Kutrowska, A. et al. Effects of binary metal combinations on zinc, copper, cadmium and lead uptake and distribution in Brassica juncea. J. Trace Elem. Med. Biol. 44, 32-39. https://doi.org/10.1016/j.jtemb.2017.05.007 (2017).

2. Moustakas, M. et al. Spatial heterogeneity of cadmium effects on salvia sclarea leaves revealed by chlorophyll fluorescence imaging analysis and laser ablation inductively coupled plasma mass spectrometry. Materials 12, 2953 (2019).

3. Zhang, H. et al. Resistance to Plasmodiophora brassicae in Brassica rapa and Brassica juncea genotypes From China. Plant Dis. 99, 776-779. https://doi.org/10.1094/PDIS-08-14-0863-RE (2015).

4. Du, J. et al. Screening of Chinese mustard (Brassica juncea L) cultivars for the phytoremediation of Cd and $\mathrm{Zn}$ based on the plant physiological mechanisms. Environ. Pollut. 261, 114213. https://doi.org/10.1016/j.envpol.2020.114213 (2020).

5. Małecka, A. et al. Insight into the phytoremediation capability of Brassica juncea (v Malopolska): Metal accumulation and antioxidant enzyme activity. Int. J. Mol. Sci. 20, 4355. https://doi.org/10.3390/ijms20184355 (2019).

6. Hanć, A. et al. Direct analysis of elemental biodistribution in pea seedlings by LA-ICP-MS, EDAX and confocal microscopy: Imaging and quantification. Microchem. J. 128, 305-311. https://doi.org/10.1016/j.microc.2016.05.008 (2016). 
7. Sarwar, N. et al. Phytoremediation strategies for soils contaminated with heavy metals: Modifications and future perspectives. Chemosphere 171, 710-721. https://doi.org/10.1016/j.chemosphere.2016.12.116 (2017).

8. Maleki, M., Ghorbanpour, M. \& Kariman, K. Physiological and antioxidative responses of medicinal plants exposed to heavy metals stress. Plant Gene 11, 247-254. https://doi.org/10.1016/j.plgene.2017.04.006 (2017).

9. Kumar, S. S., Kadier, A., Malyan, S. K., Ahmad, A. \& Bishnoi, N. R. Phytoremediation and rhizoremediation: Uptake, mobilization and sequestration of heavy metals by plants. Plant-Microbe Interact. Agro-Ecol. Perspect. 2, 367-394. https://doi.org/10.1007/ 978-981-10-6593-4_15 (2017).

10. Konkolewska, A. et al. Combined use of companion planting and PGPR for the assisted phytoextraction of trace metals $(\mathrm{Zn}, \mathrm{Pb}$, Cd). Environ. Sci. Pollut. Res. 27, 13809-13825. https://doi.org/10.1007/2Fs11356-020-07885-3 (2020).

11. Meyers, D. E. R., Auchterlonie, G. J., Webb, R. I. \& Wood, B. Uptake and localisation of lead in the root system of Brassica juncea. Pollut. Environ. 153, 323-332. https://doi.org/10.1016/j.envpol.2007.08.029 (2008).

12. Jiang, W., Liu, D. \& Hou, W. Hyperaccumulation of lead by roots, hypocotyls, and shoots of Brassica juncea. Biol. Plant. 43, 603-606. https://doi.org/10.1023/A:1002804100215 (2008).

13. Banuelos, B. G., Terry, N., Leduc, D. L., Pilon-Smits, E. A. H. \& Mackey, B. Field trial of transgenic indian mustard plants shows enhanced phytoremediation of selenium-contaminated sediment. Environ. Sci. Technol. 39, 1771-1777. https://doi.org/10.1021/ es049035f (2005).

14. Zhu, L. et al. Cadmium tolerance and accumulation in Indian mustard is enhanced by overexpressing g-glutamylcysteine synthetase. Plant Physiol. 121, 1169-1177. https://doi.org/10.1104/pp.121.4.1169 (1999).

15. Goswami, S. \& Das, S. A study on cadmium phytoremediation potential of indian mustard, Brassica juncea. Int. J. Phytorem. 17, 583-588. https://doi.org/10.1080/15226514.2014.935289 (2015).

16. Murato, M. P. et al. Effect of heavy metals in plants of the genus Brassica. Int. J. Mol. Sci. 16, 17975-17998. https://doi.org/10.3390/ ijms160817975 (2015).

17. Gurajala, H. K., Cao, X., Tang, L., Ramesh, T. \& M., Lu, M., Yang, X.,. Comparative assessment of Indian mustard (Brassica juncea L) genotypes for phytoremediation of $\mathrm{Cd}$ and $\mathrm{Pb}$ contaminated soils. Environ. Pollut. 254, 113085. https://doi.org/10.1016/j.envpol. 2019.113085 (2019).

18. Kapoor, D. et al. Modulation of the functional components of growth, photosynthesis, and antioxidant stress markers in cadmium exposed Brassica juncea L. Plants 8, 260. https://doi.org/10.3390/plants8080260 (2019).

19. Cherif, J., Mediouni, C., Ammar, W. B. \& Jemal, F. Interactions of zinc and cadmium toxicity in their effects on growth and in antioxidative systems in tomato plants (Solanum lycopersicum). J. Environ. Sci. 23, 837-844. https://doi.org/10.1016/S1001-0742(10) 60415-9 (2011).

20. Revathi, K., Ansar Ali, P. Z., Sudha, P. N. Phytoremediation Efficiency of Brassica Juncea plant from heavy metals $\mathrm{Cr}$, $\mathrm{Cu}, \mathrm{Cd}$ and $\mathrm{Pb}$ spiked Soil. International Journal of Novel Trends in Pharmaceutical Sciences 7, 174-185, https://scienztech.org/ijntps/article/ view/237/197 (2017).

21. Rajput, V. et al. Phylogenetic analysis of hyperaccumulator plant species for heavy metals and polycyclic aromatic hydrocarbons. Environ Geochem Health 43, 1629-1654. https://doi.org/10.1007/s10653-020-00527-0 (2021).

22. Kutrowska, A. \& Szelag, M. Low-molecular weight organic acids and peptides involved in the long-distance transport of trace metals. Acta Physiol. Palntarum 36, 1957-1968. https://doi.org/10.1007/s11738-014-1517-y (2014).

23. Page, V. \& Feller, U. Heavy metals in crop plants: Transport and redistribution processes on the whole plant level. Agronomy 5, 447-463. https://doi.org/10.3390/agronomy5030447 (2015).

24. Milner, M. M. \& Kochian, L. V. Investigating heavy-metal hyperaccumulation using Thlaspi caerulescens as a model system. Ann. Bot. 102, 3-13. https://doi.org/10.1093/aob/mcn063 (2008).

25. Israr, M., Jewell, A., Kumar, D. \& Sahi, S. V. Interactive effects of lead, copper, nickel and zinc on growth, metal uptake and antioxidative metabolism of Sesbania drummondii. J. Hazard. Mater. 186, 1520-1526. https://doi.org/10.1016/j.jhazmat.2010.12.021 (2011).

26. Adamakis, I. S. et al. Rapid hormetic responses of photosystem II photochemistry of clary sage to cadmium exposure. Int. J. Mol. Sci. 22, 41. https://doi.org/10.3390/ijms22010041 (2021).

27. Dobrikova, A. et al. Cadmium toxicity in Salvia sclarea L: An integrative response of element uptake, oxidative stress markers, leaf structure and photosynthesis. Ecotox. Environ. Safety 209, 111851. https://doi.org/10.1016/j.ecoenv.2020.111851 (2021).

28. Nazir, M. M., Ulhassan, Z., Zeeshan, M., Ali, S. \& Gill, M. B. Toxic Metals/Metalloids Accumulation, Tolerance, and Homeostasis in Brassica Oilseed Species. In The Plant Family Brassicaceae (Springer, 2020). https://doi.org/10.1007/978-981-15-6345-4_13.

29. Bothea, H. \& Słomka, A. Divergent biology of facultative heavy metal plants. J. Plant Physiol. 219, 45-61. https://doi.org/10.1016/j. jplph.2017.08.014 (2017)

30. Ashfaque, F., Inam, A., Inam, A., Iqbal, S. \& Sahay, S. Response of silicon on metal accumulation, photosynthetic inhibition and oxidative stress in chromium-induced mustard (Brassica juncea L.). South Afr. J. Bot. 111, 153-160. https://doi.org/10.1016/j.sajb. 2017.03.002 (2017).

31. Markovska, Y. K., Gorinova, N. J., Nedkovska, M. P. \& Miteva, K. M. Cadmium-induced oxidative damage and antioxidant responses in Brassica juncea plants. Biol. Plant. 53, 151-154. https://doi.org/10.1007/s10535-009-0023-1 (2009).

32. Ahmad, A. et al. Synergistic effects of nitric oxide and silicon on promoting plant growth, oxidative stress tolerance and reduction of arsenic uptake in Brassica juncea. Chemospere 262, 128384. https://doi.org/10.1016/j.chemosphere.2020.128384 (2021).

33. Singh, R. et al. 5-aminolevulinic acid regulates Krebs cycle, antioxidative system and gene expression in Brassica juncea L. to confer tolerance against lead toxicity. J. Biotechnol. 323, 283-292. https://doi.org/10.1016/j.jbiotec.2020.09.004 (2020).

34. Siddiqui, H., Mukhtar Ahmed, K. B., Sami, F. \& Hayat, S. Phytoremediation of cadmium contaminated soil using brassica juncea: infuence on PSII activity, leaf gaseous exchange, carbohydrate metabolism, redox and elemental status. Bull. Environ. Contam. Toxicol. 105, 411-421. https://doi.org/10.1007/s00128-020-02929-3 (2020).

35. Feigl, G. et al. Physiological and morphological responses of the root system of Indian mustard (Brassica juncea L. Czern.) and rapeseed (Brassica napus L.) to copper stress. Ecotoxicol. Environ. Saf. 94, 179-189. https://doi.org/10.1016/j.ecoenv.2013.04.029 (2013).

36. Al Mahmud, J., Hasanuzzaman, M., Nahar, K., Rahman, A. \& Fujita, M. EDTA reduces cadmium toxicity in mustard (Brassica juncea L) by enhancing metal chelation, antioxidant defense and glyoxalase systems. Acta Agrobot. 72, 1722. https://doi.org/10. 5586/aa.1772 (2019).

37. Hasanuzzaman, M. et al. Reactive oxygen species and antioxidant defense in plants under abiotic stress: Revisiting the crucial role of a universal defense regulator. Antioxidants 9, 681. https://doi.org/10.3390/antiox9080681 (2020).

38. Schaëfer, H. J., Greiner, S., Rausch, T. \& Haag-Kerwer, A. In seedlings of the heavy metal accumulator Brassica juncea Cu2+ differentially affects transcript amounts for $\gamma$-glutamylcysteine synthetase ( $\gamma$-ECS) and metallothionein (MT2). FEBS Lett. 404, 216-220 (1997).

39. Dutta, S. et al. Plants respond to abiotic factors like heavy metal stress via immediate change in expression of the stress responsive genes at the transcriptional level. Plant Signal. Behav. 13(8), e1460048. https://doi.org/10.1080/15592324.2018.1460048 (2018).

40. Ertugrul, F. et al. Abiotic stress-induced regulation of antioxidant genes in different Arabidopsis ecotypes: microarray data evaluation. Biotechnol. Biotechnol. Equip. 33(1), 128-143. https://doi.org/10.1080/13102818.2018.1556120 (2019). 
41. Cevher-Keskin, B., Yıldızhan, Y., Yüksel, B., Dalyan, E. \& Memon, R. A. Characterization of differentially expressed genes to Cu stress in Brassica nigra by Arabidopsis genome arrays. Environ. Sci. Pollut. Res. 26, 299-311. https://doi.org/10.1007/s11356-0183577-7 (2018).

42. Thakur, S., Choudhary, S. \& Bhardwaj, P. Comparative transcriptome profiling under cadmium stress reveals the uptake and tolerance mechanism in Brassica juncea. J. Plant Growth Regul. 38, 1141-1152. https://doi.org/10.1007/s00344-019-09919-8 (2019).

43. Lou, L. et al. Sulfur protects Pakchoi (Brassica chinensis L.) seedlings against cadmium stress by regulating ascorbate-glutathione metabolism. Int. J. Mol. Sci. 18, 1628. https://doi.org/10.3390/ijms18081628 (2017).

44. Doke, N. Invovement of superoxide anion generation in the hypersensitive response of potato tuber tissues to infection with an incompatible race of Phytophthora infestans and to the hyphal wall components. Physiol. Mol. Plant Pathol. 23, 345-355 (1983).

45. Patterson, B. D., Macrae, E. A. \& Ferguson, I. B. Estimation of hydrogen peroxide in plant extracts using titanium (IV). Anal. Biochem. 139, 487-492 (1984).

46. Yamamoto, Y., Kobayashi, Y., Rama Devi, S., Rikiishi, S. \& Matsumoto, H. Aluminum toxicity is associated with mitochondrial dysfunction and the production of reactive oxygen species in plant cells. Plant Physiol. 128, 63-72. https://doi.org/10.1104/pp. 010417 (2002).

47. Afzal, M. et al. Method to overcome photoreaction, a serious drawback to the use of dichlorofluorescin in evaluation of reactive oxygen species. Biochem. Biophys. Res. Commun. 304(619-624), 2003. https://doi.org/10.1016/s0006-291x(03)00641-7 (2003).

48. Levine, R. L., Williams, J. A., Stadtman, E. P. \& Shacter, E. Carbonyl assays for determination of oxidatively modified proteins. Methods Enzymol. 233, 346-357. https://doi.org/10.1016/S0076-6879(94)33040-9 (1994).

49. Bradford, M. M. A rapid and sensitive method for the quantitation of microgram quantitiesof protein utilizing the principle of protein- dye binding. Anal. Biochem. 72, 248-254. https://doi.org/10.1016/0003-2697(76)90527-3 (1976).

\section{Author contributions}

Study design, main authorship A.M. and E.R. carrying out the cultivation of plants L.C., determination of trace elements in plants A.H., determination of ROS A.M. and A.S., determination of gene transcript levels A.K., A.M. and L.C. Study design and interpretation by A.M. and E.R., W.J., graphic design of the results A.S. Manuscript preparation by all.

\section{Funding}

This research was supported by the National Center of Sciences Poland (Grant Number 2018/31/B/NZ9/01548). Additional funding was provided by the Institute of Dendrology of the Polish Academy of Sciences and Adam Mickiewicz University, Poland.

\section{Competing interests}

The authors declare no competing interests.

\section{Additional information}

Correspondence and requests for materials should be addressed to A.M.

Reprints and permissions information is available at www.nature.com/reprints.

Publisher's note Springer Nature remains neutral with regard to jurisdictional claims in published maps and institutional affiliations.

(c) Open Access This article is licensed under a Creative Commons Attribution 4.0 International (c) License, which permits use, sharing, adaptation, distribution and reproduction in any medium or format, as long as you give appropriate credit to the original author(s) and the source, provide a link to the Creative Commons licence, and indicate if changes were made. The images or other third party material in this article are included in the article's Creative Commons licence, unless indicated otherwise in a credit line to the material. If material is not included in the article's Creative Commons licence and your intended use is not permitted by statutory regulation or exceeds the permitted use, you will need to obtain permission directly from the copyright holder. To view a copy of this licence, visit http://creativecommons.org/licenses/by/4.0/.

(c) The Author(s) 2021 